\title{
Annual production enhancement at deep mining
}

\author{
Nataliia Shvaher ${ }^{1 *}$, Tetiana Komisarenko ${ }^{1}$, Serhii Chukharev $^{2}$, and Svitlana Panova ${ }^{3}$ \\ ${ }^{1}$ Kryvyi Rih National University, Department of Labor Protection and Civil Security, 11 Matusevycha \\ St., 50027 Kryvyi Rih, Ukraine \\ ${ }^{2}$ Kryvyi Rih National University, Department of Underground Mining of Mineral Deposit, \\ 11 Matusevycha St., 50027 Kryvyi Rih, Ukraine \\ ${ }^{3}$ Kryvyi Rih National University, Department of Ecology, 11 Matusevycha St., 50027 Kryvyi Rih, \\ Ukraine
}

\begin{abstract}
The article aims at determining possible annual production considering mining and technical capabilities of the underground mine. Deepening of mining operations at Kryvyi Rih iron ore basin reduces considerably annual production of the useful mineral which results in increased mining costs. To maintain annual production, it is reasonable to build the second stage of opening the depth of which depends on production volumes. When determining the optimal depth of the first stage opening, it is necessary to apply a complex research method including the graphoanalytical one for determining the underground mine's annual production and the industrial one for adjusting the methods considering technical conditions of the enterprise. It has been determined that annual production is influenced not only by mining and geological but also by mining and technical conditions. It has been proved that annual production of an underground mine decreases in direct proportion to the increased depth of mining. The speed of skips in the shaft is greatly impacted by the length of the main opening and its operating life. With the increase of the shaft operating life the skip speed decreases from 12 to $6-8 \mathrm{~m} / \mathrm{s}$. When designing the flowchart of further opening of underlying levels, it is necessary to consider both mining capabilities and technical conditions of the shaft and headgear, mining depth and the main opening operating life as well as the strategy of the mining enterprise. Consideration of the above mentioned factors enables maintaining the required annual production when mining iron ores at great depths. Under conditions of Kryvyi Rih iron ore basin, it has been determined reasonable to apply the main vertical shaft flowchart when mining reserves to the depth of $1650 \mathrm{~m}$.
\end{abstract}

\section{Introduction}

Kryvyi Rih iron ore basin accounts for 10 bn t of ferruginous quartzite mined by open-pit and underground methods. Nearly $1.1 \mathrm{bn} t$ is made by rich ores with the useful mineral component of over $60 \%$ which is mined by the underground method. When mining underground to the depth of up to $1115 \mathrm{~m}$, the designed annual production of underground

\footnotetext{
* Corresponding author: knu.shwager@gmail.com
} 
mines made $4-8$ mln t $[1-3]$.

Underground mining of iron ores has deteriorated mining-geological and miningtechnical conditions resulting in $2-3$-fold decrease of annual production and 1.5-2.5-fold increase of mining costs. Currently, iron ore is mined at the depth of over $1300 \mathrm{~m}$ by traditional mining systems: bulk caving and open stoping. Ore drawing is performed by obsolete equipment (slusher or vibrofeeder), then ore is transported in cars to the shaft and by 50 t-skips to the surface $[4-6]$.

The process chain of the kind has not only decreased capacity of Kryvyi Rih iron ore basin underground mines to $1.5-2.5 \mathrm{mln} t$ but also increased the injury and occupational disease rates [7-10]. Mining enterprises are making efforts to eliminate the above mentioned drawbacks by purchasing import mobile equipment, installing powerful hoisting machines, improving mining systems, enhancing labour conditions, etc. However, the mine production capacity of $4 \mathrm{mln} \mathrm{t} / \mathrm{year}$ has not yet been reached.

It should be noted that with small production volumes of $1.5-2.5 \mathrm{mln}$ tpa, marketable products make $1.2-2.0 \mathrm{mln} \mathrm{t}$, waste rocks account for $0.3-0.5 \mathrm{mln}$ t. The latter are stockpiled in external dumps or caving zones and aggravate the regional environment.

\section{Methods}

Leading scientists are constantly solving problems of increasing annual production and decreasing mining costs through development of innovative highly efficient technologies, complex mining of useful mineral deposits, enhancement of mining systems and increase of the useful mineral content in the mined ore mass.

Thus, to increase output of marketable products there are suggested open stope systems $[11-14]$. This will enable increase of marketable product volumes by $5-10 \%$. However, considering mining and geological conditions, this system cannot be $100 \%$ applicable, so on the whole the amount of marketable products at the underground mine is $2-5 \%$ larger.

When applying bulk caving, [15-18] suggest application of underground magnetic separation to increase production volumes by $15 \%$. However, this technology cannot be widely applied as there are 5-9 mineralogical and technological types of ore in the massif on average [19 - 21] and this will lead to frequent change of settings of the technological concentration equipment.

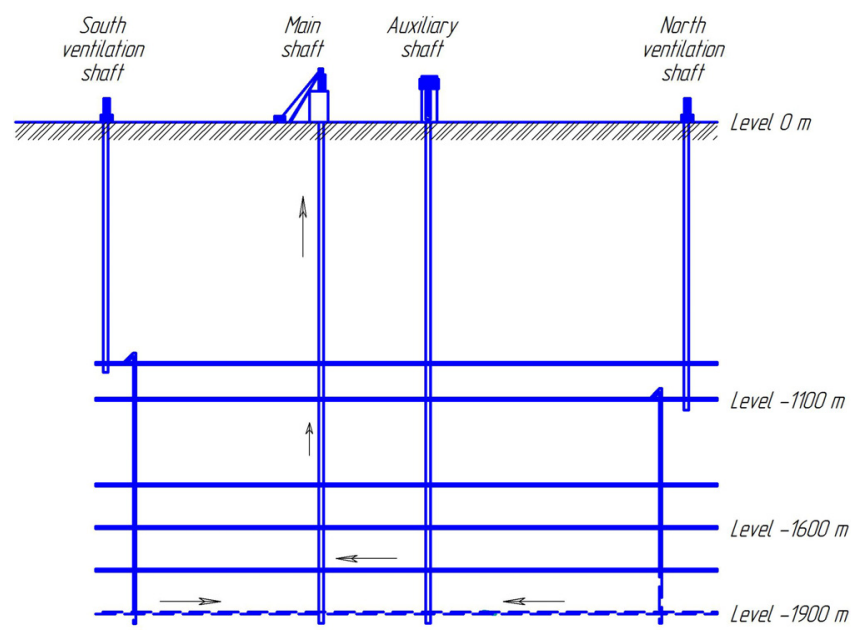

Fig. 1. The basic diagram of opening the Kryvyi Rih iron ore basin deposit by the main shaft to the final depth. 
Nevertheless, it should be noted that increase of the depth of the first stage of opening to $1500-1700 \mathrm{~m}$ will inevitably result in decreased annual production due to longer periods for ore mass hoisting and increased loads on constructive elements of the headgear, Fig. 1. All these factors may affect negatively mining costs and worker safety [22 - 27].

Thus, it is necessary to substantiate the maximum depth of the first stage of opening that will provide high mine production and safe labour conditions.

\section{Results and discussion}

When determining annual production of the underground mine, the formula characterizing only mining capacity of the enterprise is used:

$$
A=S \cdot V_{S} \cdot \gamma \cdot \frac{1-P}{1-R} \cdot 10^{-6} \mathrm{mln} \mathrm{t} / \mathrm{year},
$$

where $S$ is the total horizontal operational area of the deposit, $\mathrm{m}^{2} ; V_{s}$ is the average annual decrease of stoping, $\mathrm{m} /$ year; $\gamma$ is the specific weight, $\mathrm{t} / \mathrm{m}^{3} ; P, R$ are extraction values with relation to ore losses and dilution at underground mining, fraction units.

It should be noted that annual production according to formula (1) is not impacted by the mining depth. That is why, when determining annual production of the underground mine at great depths, the mining depth, as well as the current condition and prospects of the mining enterprise's performance should be taken into consideration.

So, the underground mine's annual production by hoisting capacities per main rock shaft equipped with two balanced skips is determined by the expression:

$$
A_{h}=\frac{60 \cdot T \cdot Q \cdot k_{n} \cdot t_{d}}{t} \cdot \frac{1-P}{1-R} \cdot 10^{-6} \mathrm{mln} \mathrm{t} / \mathrm{year},
$$

where $T$ is the time of the hoister work during a year period, days; $Q$ is the skip capacity, t; $k_{n}=0.85-0.90$ is the skip fill factor, fraction units; $t_{d}$ is the hoister work time during a day (considering idle and maintenance time), hours; $t$ is the time of one hoister's cycle, min.

The time of one hoister's cycle for loading, unloading and hoisting is determined by the formula:

$$
t=t_{n . p}+t_{p}+t_{p . t} \min ,
$$

where $t_{n . p}=1-3$ is the time for loading (unloading) a skip, min.; $t_{p}$ is the time of the skip moving along the shaft, min.; $t_{p . t}=1-2$ is the time for placing the skip for loading (unloading) and reaching the required speed, min.

The time of the skip movement along the shaft is determined by the formula:

$$
t_{p}=H /(v \cdot 60) \min ,
$$

where $H$ is the height of hoisting in the shaft (accepted equal to the depth of mining according to the norms of the technological design for the first stage of opening), $\mathrm{m} ; v$ is the skip speed in the shaft, $\mathrm{m} / \mathrm{s}$. The skip speed depends on the technical condition of the shaft.

Analysis of the project design documentation and Kryvbas mining enterprises' practice enables the conclusion that when mining deposits below $1100 \mathrm{~m}$, the skip speed decreases by $3-7 \%$ every 10 years of shaft operation.

Calculations of annual production of the underground mine depending on mining systems applied are given in Figs. 2 and 3.

Fig. 2 shows that when mining reserves by the bulk caving system, increased depths of the first stage of opening from 1200 to $1900 \mathrm{~m}$ results in decreased annual production of the 
underground mine from 7.5 to $1.0 \mathrm{mln}$ tpa, mine annual production by mining capacity at that being $5.5 \mathrm{mln} t$ and the current average production making $1.8 \mathrm{mln} \mathrm{t}$. The diagrams in Fig. 2 demonstrate that to maintain the current production at the level of $1.8 \mathrm{mln} \mathrm{t}$, it is necessary to build the second stage of opening (further mining by sub-vertical shafts) below $1600 \mathrm{~m}$.

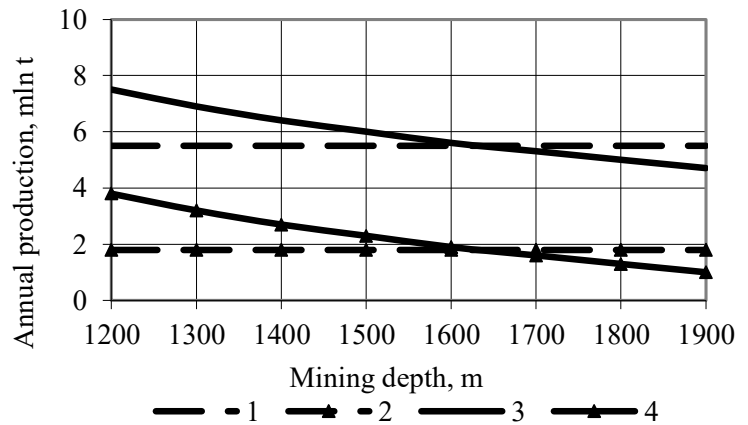

Fig. 2. Dependence of the underground mine annual production on the mining depth when applying the bulk caving system: 1 - by mining capacities; 2 - current production; 3,4 - skip speed in the shaft: maximum $(12 \mathrm{~m} / \mathrm{s})$ and current $(8 \mathrm{~m} / \mathrm{s})$ respectively.

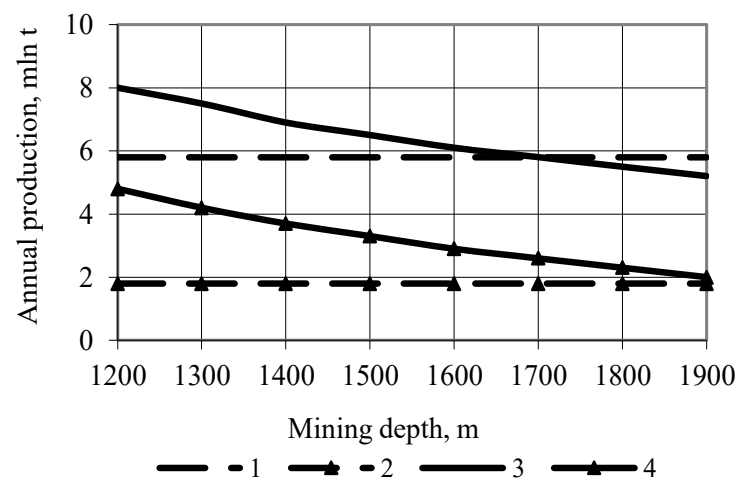

Fig. 3. Dependence of the underground mine annual production on the mining depth when applying the filling system: 1 - by mining capacities; 2 - current production; 3, 4- skip speed in the shaft: maximum $(12 \mathrm{~m} / \mathrm{s})$ and current $(8 \mathrm{~m} / \mathrm{s})$ respectively.

Also, annual production may be increased at the expense of the increased skip speed in the shaft from 8 to $12 \mathrm{~m} / \mathrm{s}$. However, this will result in increased capital expenditures.

The rough value of capital expenditures is determined by the formula:

$$
K=0.1 \cdot Q^{0.77} \mathrm{ccu} / \mathrm{t}
$$

where $Q$ is the balance ore reserves, $\mathrm{mln}$ t.

Considering the fact that there is still about $150 \mathrm{mln} \mathrm{t}$ within the boundaries of the deposit, according to formula (5) total unit costs make about 4.7 conditional currency units (ccu) per ton when mining by sub-vertical shafts. In case of reconstructing the main shaft when deepening it to $1900 \mathrm{~m}$, unit costs will grow by $1.2 \mathrm{ccu} / \mathrm{t}$ when putting each level into operation. Thus, total unit costs when mining the deposit by main shaft to the depth of $1900 \mathrm{~m}$ with the skip speed of $12 \mathrm{~m} / \mathrm{s}$ make $9.5 \mathrm{ccu} / \mathrm{t}$ which is by $4.8 \mathrm{ccu} / \mathrm{t}$ greater than at building the second stage of opening. 
Application of the room-and-pillar system with consolidating backfill enables mining enterprises to mine reserves up to the depth of $1900 \mathrm{~m}$ by one main shaft with the same annual production (see Fig. 1). It should be noted that according to data of mining enterprises mining costs of 1 ton of ore will increase by $2.5-3.0 \mathrm{ccu}$.

However, this requires additional alienation of land, extra technological chains, sequence of mining operations and clear work organization. .

The following flowcharts of opening on the second stage are possible for Kryvbas conditions: by a sub-vertical shaft with skip transportation of ore; by inclined spiral ramps with ore haulage by powerful trucks; by an inclined sub-vertical shaft with a conveyer.

Aggregate economic indicators by variants of opening and mining with the help of the second stage of opening are given in Table 1.

Table 1. Aggregate economic indicators by opening flowcharts.

\begin{tabular}{|l|c|c|c|}
\hline \multicolumn{1}{|c|}{ Indicators } & $\begin{array}{c}\text { Sub-vertical } \\
\text { shaft }\end{array}$ & Spiral ramp & $\begin{array}{c}\text { Inclined sub- } \\
\text { vertical shaft }\end{array}$ \\
\hline Proven reserves, mln t & 150.0 & 150.0 & 150.0 \\
\hline Annual production, mln t & $2.0-4.0$ & $2.0-8.0$ & $2.0-12.0$ \\
\hline $\begin{array}{l}\text { Expenditures on reconstruction of underground } \\
\text { complex, mln ccu }\end{array}$ & 0.85 & 0.69 & 0.77 \\
\hline $\begin{array}{l}\text { Expenditures on building underground complex, } \\
\text { mln ccu }\end{array}$ & 1.56 & 1.73 & 1.62 \\
\hline Expenditures on additional workings, mln ccu & 0.05 & 0.06 & 0.09 \\
\hline Total capital expenditures, mln ccu & 2.46 & 2.48 & 2.48 \\
\hline Total unit costs, ccu/t & 0.0164 & 0.0165 & 0.0165 \\
\hline $\begin{array}{l}\text { Operating costs per year (to the second opening } \\
\text { stage), mln ccu/t }\end{array}$ & 0.058 & 0.065 & 0.047 \\
\hline Total, annual expenditures, ccu/t & 0.07444 & 0.0815 & 0.0635 \\
\hline
\end{tabular}

As is seen from Table 1, the most efficient is the flowchart of opening by a vertical shaft to the depth of $1600 \mathrm{~m}$ and by an inclined sub-vertical shaft. The flowchart provides minimum unit costs of $0.0635 \mathrm{ccu} / \mathrm{t}$ with annual production of the underground mine of 2.0 to $12.0 \mathrm{mln} \mathrm{t}$. But, as is seen from the practice of opening the deposits of Kryvyi Rih iron ore basin at Artem-1 underground mine, labour conditions of conveyer workers are greatly deteriorated.

Considering leading foreign practices, reserves of Kryvyi Rih iron ore basin below $1600 \mathrm{~m}$ are reasonable to be mined by using opening by a vertical shaft up to the depth of $1600 \mathrm{~m}$ and by an inclined spiral ramp applying import mobile equipment. According to calculations, the greatest expenses under this flowchart fall to the share of exploitation due to servicing the mobile equipment as compared with the national equipment.

The research conducted results in the following flowchart of opening the deposit applying the second opening stage (Fig. 4).

The flowchart involves the following: the vertical shafts are deepened along with mining the underlying levels up to the depth that provides the required annual production of the underground mine according to formula (1). The lower opening is conducted by the second opening stage.

Ore mass from deep levels is hoisted by underground trucks from breakage faces on the spiral ramp to the loading point at the $-1600 \mathrm{~m}$ level. At the spiral ramp mouth a loading point is established for re-loading ore from trucks into cars and further transporting to the main shaft.

The advantages of the variant are the following: increased annual production of the underground mine; fast putting into operation of mining levels below $-1600 \mathrm{~m}$; decreased length of workings; decreased capital and operating costs for the second stage of opening. 


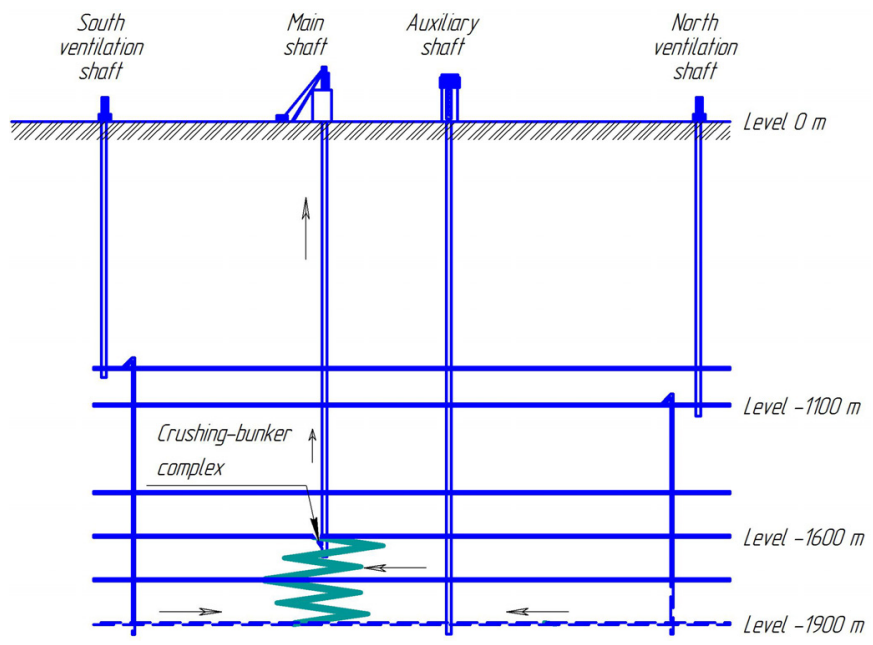

Fig. 4. The diagram of opening Kryvyi Rih iron ore basin deposits with the spiral ramp below the depth of $1600 \mathrm{~m}$.

The disadvantage of the flowchart is dependence of the mine annual production on hoisting capacities of the main vertical shaft.

At Kryvyi Rih iron ore basin, to increase annual production, it is reasonable to combine underground mines into a single transportation system, Fig. 5.

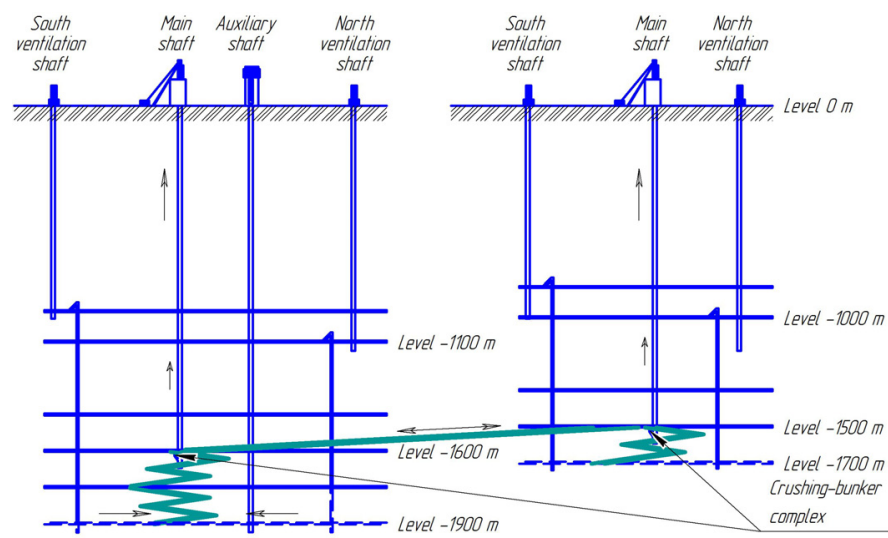

Fig. 5. The diagram of opening Kryvyi Rih iron ore basin deposits with combining mine fields and driving a spiral ramp below the depth of $1600 \mathrm{~m}$ and a single transport working.

Application of the method enables doubled annual production within the mine field and further development of underlying levels. Also, this will enable preserving employment, decreasing expenditures on building the second opening stage and providing distribution of the mined ore mass according to the useful component content.

At the depth of $1600 \mathrm{~m}$ main shafts are connected with the working for electric transport that will enable simultaneous quality grading of ore from the two underground mines.

The advantage of the flowchart presented in Fig. 5 is the fact that it is reasonable to apply a single transport working to hauling not only ore mass but also waste rocks. This will enable using only one shaft for hoisting waste rock, thus using efficiently the shaft capacity for hoisting waste rock of one mine field and then using the shaft for hoisting waste rock for hoisting ore of the other underground mine. 
The disadvantages of the flowchart are considerable capital investment for purchasing mobile equipment; additional operating costs for maintaining the loading point working; complexity of ventilating the second stage of opening; necessary maintenance of the concentration level $(-1600 \mathrm{~m})$; clear organization of mining operations.

Efficiency of the presented scientific results depends on their implementation in projects on developing systems of forecasting and providing reliability of current mining enterprises or those being designed or their subdivisions. It should be noted that practical implementation of the suggested scientific results provides for mainly development of information technologies and software according to the presented methods. This enables significant reduction of expenditures on implementation as the software is characterized by: rather low costs for its porting and adapting to new production conditions; high degree of reliability provided by powerful means of testing and adjustment at early stages of development. The cost of modernization of functional capabilities of the given system of forecasting and providing objects' reliability is rather low as it will only require the current software upgrade.

\section{Conclusions}

The research conducted enables determining the fact that annual production of the underground mine impacts significantly the choice of an opening flowchart when mining reserves at great deaths. If underground mine annual production does not exceed $2 \mathrm{mln} t$, opening is performed to the depth of $1900 \mathrm{~m}$. At that, it should be taken into account that operating costs for maintaining the shaft and headgear increase. That is why, not only technical but also economic components should be considered when determining annual production of an underground mine.

Combination of underground mine fields will considerably facilitate growth of economic indicators at the expense of increased annual production and distribution of the mined ore mass according to the useful component content.

The work was supported by the Ministry of Education and Science of Ukraine within the framework of state scientific project "Determination of regularities of the stress-strain state of rocks disturbed by workings with the purpose of developing resource-saving ore mining technologies" (State registration No. 0115U003179).

\section{References}

1. Pysmennyi, S., Brovko, D., Shwager,N., Kasatkina, I., Paraniuk, D., \& Serdiuk, O. (2018). Development of complex structure ore deposits by means of chamber systems under conditions of the Kryvyi Rih iron ore field. Eastern-European Journal of Enterprise Technologies, 5(1(95)), 33-45. https://doi.org/10.15587/1729-4061.2018.142483

2. Stupnik, N., Kalinichenko, V., Pismennij, S., \& Kalinichenko, E. (2015). Features of underlying levels opening at "ArsellorMittal Kryvyic Rih" underground mine. New Developments in Mining Engineering 2015 - Theoretical and Practical Solutions of Mineral Resources Mining, 39-44. https://doi.org/10.1201/b19901-8

3. Stupnik, M.I., Kalinichenko, V.O., Kalinichenko, O.V., Muzika, I.O., Fed'ko, M.B., \& Pismennyi, S.V. (2015). The research of strain-stress state of magnetite quartzite deposit massif in the condition of mine "Gigant-Gliboka" of central iron ore enrichment works (CGOK). Metallurgical and mining industry, (7), 377-383.

4. Khomenko, O., \& Rudakov, D. (2010). The first Ukrainian corporative university. Technology of support of workings near to extraction chambers. New Techniques and Technologies in Mining Proceedings of the School of Underground Mining, 203-206. https://doi.org/10.1201/b11329-34. 
5. Stupnik, N., Kalinichenko, V., \& Pismennyi, S. (2013). Pillars sizing at magnetite quartzites room-work. Annual Scientific-Technical Collection - Mining of Mineral Deposits 2013, 11-15. http://dx.doi.org/10.1201/b16354-4

6. Khomenko O.Ye., Sudakov, A.K., Malanchuk, Z.R., \& Malanchuk, Ye.Z. (2017). Principles of rock pressure energy usage during underground mining of deposits. Naukovyi Visnyk Natsionalnoho Hirnychoho Universytetu, 2(158), 34-43.

7. Stupnik, M.I., Kalinichenko, V.O., Pysmennyi, S.V., \& Kalinichenko, O.V. (2018). Determining the qualitative composition of the equivalent material for simulation of Kryvyi Rih iron ore basin rocks. Naukovyi Visnyk Natsionalnoho Hirnychoho Universytetu, (4), 21-27. https://doi.org/10.29202/nvngu/2018-4/4

8. Kalinichenko, V., Pysmennyi, S., Shvaher, N., Kalinichenko, O. (2018). Selective underground mining of complex structured ore bodies of Kryvyi Rih Iron Ore Basin. E3S Web of Conferences, (60), 00041. https://doi.org/10.1051/e3sconf/20186000041

9. Fed'ko, M.B., Kolosov, V.A., Pismennyy, S.V., \& Kalinichenko, Ye.A. (2014). Ekonomicheskie aspekty perekhoda na bestrotilovye vzryvchatye veshchestva pri podzemnoy dobyche rud $\mathrm{v}$ Krivorozhskom basseyne. Naukovyi Visnyk Natsionalnoho Hirnychoho Universytetu, (4), 79-84.

10. Tarasyutin, V.M. (2015). Geotechnology features of high quality martite ore from deep mines of Kryvyi Rih basin. Naukovyi Visnyk Natsionalnoho Hirnychoho Universytetu, (1), 54-60.

11. Vladyko, O., Kononenko, M., \& Khomenko, O. (2012). Imitating modeling stability of mine workings. Geomechanical Processes During Underground Mining - Proceedings of the School of Underground Mining, 147-150. https://doi.org/10.1201/b13157-26

12. Khomenko, O., Kononenko, M., \& Petlovanyi, M. (2015). Analytical modeling of the backfill massif deformations around the chamber with mining depth increase. New Developments in Mining Engineering 2015: Theoretical and Practical Solutions of Mineral Resources Mining, 265-269. https://doi.org/10.1201/b19901-47

13. Stupnik, M., Kolosov, V., Kalinichenko, V., \& Pismennyi, S. (2014). Physical modeling of waste inclusions stability during mining of complex structured deposits. Progressive Technologies of Coal, Coalbed Methane, and Ores Mining, 25-30. https://doi.org/10.1201/b17547-6

14. Khomenko, O., Kononenko, M., \& Danylchenko, M. (2016). Modeling of bearing massif condition during chamber mining of ore deposits. Mining of Mineral Deposits, 10(2), 40-47. https://doi.org/10.15407/mining10.02.040

15. Stupnik, N., Kalinichenko,V., Kolosov, V., Pismennyi, S., \& Shepel, A. (2014). Modeling of stopes in soft ores during ore mining. Metallurgical and mining industry, (3), 32-36.

16. Morkun, V., Morkun, N., \& Pikilnyak, A. (2014) Simulation of high-energy ultrasound propagation in heterogeneous medium using k-space method. Metallurgical and Mining Industry, (3), 23-27.

17. Morkun, V., Morkun, N., \& Pikilnyak, A. (2014). Simulation of the Lamb waves propagation on the plate which contacts with gas containing iron ore pulp in Waveform Revealer toolbox. Metallurgical and Mining Industry, (5), 16-19.

18. Morkun, V., Morkun, N., \& Pikilnyak, A. (2014) Ultrasonic phased array parameters determination for the gas bubble size distribution control formation in the iron ore flotation. Metallurgical and Mining Industry, (3), 28-31.

19. Morkun, V., \& Tron, V. (2014) Ore preparation energy-efficient automated control multi-criteria formation with considering of ecological and economic factors. Metallurgical and Mining Industry, (5), 8-10.

20. Morkun, V., \& Tron, V. (2014) Automation of iron ore raw materials beneficiation with the operational recognition of its varieties in process streams. Metallurgical and Mining Industry, (6), 4-7.

21. Morkun, V., Morkun, N., \& Pikilnyak, A. (2015). The study of volume ultrasonic waves propagation in the gas-containing iron ore pulp. Ultrasonics, (56), 340-343.

22. Andreev, B.M., Brovko, D.V., \& Khvorost, V.V. (2015). Determination of reliability and justification of object parameters on the surface of mines taking into account change-over to the 
lighter enclosing structures. Metallurgical and mining industry, (12), 378-382.

23. Fedko, M.B., Muzyka, I.O., Pysmennyi, S.V., \& Kalinichenko, O.V. (2019). Determination of drilling and blasting parameters considering the stress-strain state of rock ores. Naukovyi Visnyk Natsionalnoho Hirnychoho Universytetu, (1), 37-41. https://doi.org/10.29202/nvngu/2019-1/20

24. Stupnik, N.I., Kalinichenko, V.A., Kolosov, V.A., Pismenniy, S.V., \& Fedko M.B. (2014). Testing complex-structural magnetite quartzite deposits chamber system design theme. Metallurgical and mining industry, (2), 89-93.

25. Bondarenko, V., Kovalevska, I., Astafiev, D., Malova, O. (2018). Examination of phase transition of mine methane to gas hydrates and their sudden failure - Percy Bridgman's effect. Solid State Phenomena, (277), 137-146. https://doi.org/10.4028/www.scientific.net/ssp.277.137

26. Piwniak, G.G., Bondarenko, V.I., Salli, V.I., Pavlenko, I.I., \& Dychkovskiy, R.O. (2007). Limits to economic viability of extraction of thin coal seams in Ukraine. Technical, Technological and Economic Aspects of Thin-Seams Coal Mining International Mining Forum 2007, 129-132. https://doi.org/10.1201/noe0415436700.ch16

27. Pivnyak, G.G., Pilov, P.I., Bondarenko, V.I., Surgai, N.S., \& Tulub, S.B. (2005). Development of coal industry: The part of the power strategy in the Ukraine. Gornyi Zhurnal, (5), 14-17. 